International Research Journal of Management, IT \& Social Sciences
Available online at https://sloap.org/journals/index.php/irjmis/
Vol. 7 No. 1, January 2020, pages: 217-226
ISSN: 2395-7492
https://doi.org/10.21744/irjmis.v7n1.839

\title{
Role of Consumer Satisfaction in Mediating Effect of Product Quality on Repurchase Intention
}

Dewa Ayu Taman Sari ${ }^{\text {a }}$ I. G. A. K. Giantari ${ }^{\text {b }}$

Article history:

Submitted: 09 November 2019

Revised: 18 December 2019

Accepted: 13 January 2020

\section{Keywords:}

intention;

product;

quality;

repurchase;

satisfaction;

\begin{abstract}
The purpose of this study is to explain the effect of product quality on consumer satisfaction and repurchase intention Berrybenka.com consumers in the city of Denpasar. The sample used was Berrybenka.com consumers in the city of Denpasar with a total of 105 respondents with a sample collection technique using purposive sampling. This research uses PLS (Partial Least Square) analysis technique. The results found that the quality of the product had a significant positive effect on repurchase intentions. Product quality has a significant positive effect on customer satisfaction. Consumer satisfaction has a significant positive effect on repurchase intentions. Consumer satisfaction acts as a partial mediating variable on the effect of the relationship of product quality on repurchase intentions. The implications of this study indicate that to increase the repurchase intention of its products, Berrybenka.com should need to pay attention to the factors of product quality and customer satisfaction. To maintain and increase market share, Berrybenka.com needs to maintain the quality of its products. Good product quality will increase customer satisfaction and encourage repurchase intentions of Berrybenka.com consumers in the future.
\end{abstract}

International research journal of management, IT and social sciences (C) 2020. This is an open access article under the CC BY-NC-ND license (https://creativecommons.org/licenses/by-nc-nd/4.0/).

Corresponding author:

Dewa Ayu Taman Sari,

Faculty of Economics and Business, Udayana University, Denpasar, Indonesia.

Email address: ayutamansari@gmail.com

Udayana University, Denpasar, Indonesia

${ }^{\mathrm{b}}$ Udayana University, Denpasar, Indonesia 


\section{Introduction}

Consumer satisfaction becomes an important thing. According to Irnandha (2016), to win a competition, companies must be able to give satisfaction to customers. Efforts will be made by the company to satisfy the needs of consumers with a variety of strategies and various ways in the hope that customers feel satisfied and then want to come back to another company. Irnandha (2016), also explained that customer satisfaction is a very decisive factor in marketing, on the contrary, customer disappointment in providing services can make the company's destruction in the future. The importance of customer satisfaction for business people is inseparable from the quality of the products they offer. Assauri (2015), said that in a competitive condition every company in maintaining and increasing its sales and market share needs to make efforts to improve and change the products resulting in a better direction so as to provide greater efficiency and satisfaction. Product quality is something that needs to get the main attention of the company or manufacturer, considering the quality of a product is closely related to the problem of customer satisfaction (Assuari, 2015).

Research conducted by Pesoth (2015) shows the relationship between product quality and consumer satisfaction where the results of the study found that product quality has an effect on customer satisfaction of a cigarette brand in the city of Manado. Oghojavor et al. (2014), conducted a study of the satisfaction of consumers of telecommunications service users in Nigeria, the results of the study showed that the products offered by telecommunications industry companies had a high influence on the satisfaction of consumers of telecommunications service users in the country. The fulfillment of customer satisfaction in the performance of the marketing division will be expected to be able to encourage repurchase intentions for consumers of the company's products. In online shopping Lin \& Lekhawipat (2014), says that customers who have developed online shopping habits have an increase in repurchase intentions through customer satisfaction. Research conducted by Yulianti et al. (2014), also showed that consumer satisfaction is one of the national retailers that had a significant positive effect on customer purchase intentions at the store.

Mirabi et al. (2015), investigated the factors influencing the purchase intention of Bono brand tile customers, based on the results of this study, product quality variables, and advertising brands and names had the highest impact on customer purchase intentions where customers paid more attention. This is according to Mirabi et al. (2015) will result in continuous product quality improvement that can bring high results for the company. The findings made by Sullivan et al. (2018), shows the product evaluation factor, namely the quality perceived by consumers is important in determining repurchase intentions. Research conducted by Goh et al. (2016), shows that product attributes significantly influence consumer intentions for repeat purchases. Sulaiman et al. (2017), examined the online purchase intention and found that product factors were the factors that most influence online purchase intention. Jefry et al. (2014), tested the role of mineral water product package quality in packaging and the results showed that thicker water bottles were considered to be of higher quality compared to thinner bottled water bottles and this difference ultimately affected customers in encouraging repurchase intentions (Saputra et al., 2019).

\section{Literature review}

\section{H1: Product quality has a positive and significant effect on repurchase intentions}

Good product quality will later provide satisfaction for consumers who have consumed the product. According to Kotler \& Keller (2009), consumer satisfaction depends on the quality of a product. Zhang et al. (2013), found that customer satisfaction is determined by the performance of product attributes where to satisfy customer management must first identify the performance of various attributes so that management is required to invest in product attributes to achieve the highest level of satisfaction. Research conducted by Pesoth (2015), also shows that product quality has an effect on cigarette customer satisfaction. Razak et al. (2016), found that product quality affects consumer satisfaction of toothpaste products.

According to Ishaq et al. (2014), companies recognize that quality can be an important differentiator among themselves from their competitors. Today's consumers are more worried about the quality of the final product than the process that turns it into reality. The results of his research also showed that product quality has a significant effect on customer satisfaction. Megatef (2015), found that products are the strongest variable on customer satisfaction where quality involves determining quality standards for products and applying guarantee methods at the level of staff and facility performance. 
H2: Product quality has a positive and significant effect on customer satisfaction.

Consumer satisfaction is an important thing to consider in business. Consumer satisfaction will encourage consumers to buy and re-consume the products they have consumed (Martini et al., 2018). Lin (2014), found that consumer satisfaction is a vital driver of repurchase intentions for online shopping, Chang et al. (2014), also found that customer satisfaction had a significant effect on repurchase intention and Yulianti (2014) found that satisfaction had a positive and significant effect on customer purchase intentions. Adekunle \& Jones (2018), conducted research conducted in Nigeria on smartphone products showing that the repurchase intention a smartphone in that country is influenced by the satisfaction felt by consumers of these products. Domfeh et al. (2018), conducted a study of University of Cape Coast students and found that consumer satisfaction could influence purchase intentions in students in Ghana.

\section{H3. Consumer satisfaction has a significant positive effect on repurchase intentions.}

Consumer satisfaction is one of the company's goals that must be achieved in order to bridge the quality of a company's products in order to increase the repurchase intention of the company's products. Research conducted by Ishaq et al. (2014) shows the role of customer satisfaction as a mediating variable of perceived quality, corporate image and customer value on customer loyalty. The role of mediation by consumer satisfaction is also seen in research conducted by Domfeh et al. (2018), the research shows that customer satisfaction can mediate celebrity advertising and celebrity personality towards purchase intention in the telecommunications industry in Ghana. Chang et al. (2014), found that consumer satisfaction had a significant effect on repurchase intention on food products sold online in Taiwan. Goh et al. (2016), also shows the mediating role of customer satisfaction in the influence of product attributes on the intention to repeat purchases of smartphone products in Malaysia. Research conducted by Moeslehi \& Farideddin (2016), consumer satisfaction is influenced by the price promotion of coffee shop products in Isfahan and then consumer satisfaction affects the intention of repeated product purchases.

H4: Consumer satisfaction mediates the effect of product quality on repurchase intentions.

\section{Materials and Methods}

The scope of the study includes several variables related to customer satisfaction and online repurchase intention where customer satisfaction and online repurchase intention are explained by product quality. The research location covers Denpasar City with the consideration that Denpasar City has the highest consumption of fashion products in the Province of Bali which is expected to be able to contribute to the development of the company's business. The population, in this case, is the people of Denpasar City who have made purchases of fashion needs on Berrybenka.com. The sampling technique uses a purposive sampling technique in which the sample is based on certain considerations (Sugiyono, 2017). The determination of the sample in this study refers to the opinion of Ferdinand (2014) which states that the sample size depends on the number of indicators multiplied by 5 to 10 . The total number of all indicator variables used in this study is 15 indicators multiplied by 7 to 105 respondents. This research uses Structural Equation Modeling (SEM) analysis technique with Partial Least Square (PLS) approach. PLS is a powerful analytical method because it does not assume the data must be of a certain scale measurement, the number of samples is small, can be used to confirm the theory, and helps to obtain latent variables for predictive purposes.

\section{Results and Discussions}

\section{Evaluate the structure model or inner model}

Testing the inner model or structural model is done to see the relationship between the construct, significance value and R-square of the research model. The structural model is evaluated using R-square for the dependent construct and $\mathrm{t}$-test as well as the significance of the coefficient of structural path parameters.

Sari, D. A. T., \& Giantari, I. G. A. K. (2020). Role of consumer satisfaction in mediating effect of product quality on repurchase intention. International Research Journal of Management, IT and Social Sciences, 7(1), 217-226. 
Table 1

R-square

\begin{tabular}{ll}
\hline Construct & R Square \\
\hline Consumer Satisfaction & 0.567 \\
Repurchase Intention & 0.672 \\
\hline
\end{tabular}

Primary Data, 2019

In table 1 it can be seen if the R-square value of the repurchase intention variable is 0.672 . It can be interpreted that $67.2 \%$ of the variability of the repurchase intention construct is explained by the variable of customer satisfaction and product quality, while $32.8 \%$ of the repurchase intention variable is explained by variables outside the model. Likewise, the variable of customer satisfaction, $56.7 \%$ is explained by product quality, while $43.3 \%$ of the variable of customer satisfaction is explained by variables outside the model. In addition to using R-square, the goodness of fit, the model is also measured using Q-Square prediction relevance for structural models, measuring how well the observations produced by the model and also the estimated parameters. Q-Square value $>0$ indicates the model has predicate relevance, conversely if the $\mathrm{Q}-\mathrm{Square}$ value $\leq 0$ indicates the model does not have predicate relevance. Based on Table 1 , the predictive value of relevance $\left(Q^{2}\right)$ can be calculated, namely:

$$
\begin{aligned}
Q^{2} & =1-\left(1-R_{1}^{2}\right)\left(1-R_{2}^{2}\right) \\
& =1-(1-0.672)(1-0,567) \\
& =1-(0,328)(0,433) \\
& =1-0,142 \\
& =0,857
\end{aligned}
$$

The results of this calculation indicate that the value of $\mathrm{Q}^{2}$ is greater than $0(0.857)$, so it can be interpreted that the model is good because it has a relevant predictive value, which is $85.7 \%$. This shows that variations in repurchase intention variables can be explained by the variables used, namely product quality and customer satisfaction, while the remaining $14.3 \%$ is explained by other variables that have not been included in the model.

\section{Hypothesis test}

The significance of the estimated parameters provides very useful information about the relationship between the research variables. The basis used in testing hypotheses is the probability value (p-value) contained in the output path coefficients presented in Table 2 below:

Table 2

Path coefficients

\begin{tabular}{lllll}
\hline Constructs & Path Coefficients & T Statistics & P Values & Description \\
\hline Consumer Satisfaction -> Repurchase Int & 0,456 & 3,287 & 0,001 & Accepted \\
Product Quality -> Consumer Satisfaction & 0,753 & 11,567 & 0,000 & Accepted \\
Product Quality -> Repurchase Int & 0,419 & 2,864 & 0,004 & Accepted \\
\hline
\end{tabular}

Primary Data, 2019

Hypothesis testing can be done using t-statistics or by looking at the p-value with Alpha used at 0.05 . If the t-statistic value $\geq \mathrm{t}$-table value $(1.98350)$ or $\mathrm{p}$-value $<0.05$, the research hypothesis is accepted. In Table 5.11 it can be seen that consumer satisfaction with repurchase intentions has a correlation coefficient of 0.456 ; with the t-statistics value of $3.287(3.287 \geq 1.98350)$ and a $p$-value of $0.001(0,000<0.05)$, the research hypothesis was accepted. This shows that there is a positive influence between consumer satisfaction variables on repurchase intentions. The higher the customer satisfaction of Berrybenka.com, the higher the repurchase intention Berrybenka.com fashion products. The product quality variable on repurchase intention has a correlation coefficient of 0.419 ; with the t-statistics value of 2.864 (2.864 $\geq 1.98350)$ and with a p-value of $0.004(0.004<0.05)$, the research hypothesis was accepted. This shows that there is a positive influence between product qualities on repurchase intentions. The higher the quality of fashion products provided by Berrybenka.com, the higher the repurchase intention Berrybenka.com consumers in the city of Denpasar. 
Furthermore, product quality variables on customer satisfaction have a correlation coefficient of 0.753 ; with a $\mathrm{t}$ statistics value of $11,567(11,567 \geq 1,98350)$ and with a $p$-value of $0,000(0,000<0.05)$, the research hypothesis was accepted. This shows that there is a positive influence on product qualities on customer satisfaction. The higher the quality of fashion products provided by Berrybenka.com, the more satisfied Berrybnka.com consumers are in Denpasar. Based on the explanation above, it can be concluded that the hypothesis in this study is entirely accepted.

\section{The Role of customer satisfaction on mediating the effect of product quality on repurchase intentions}

The results of testing the direct effect of product quality on repurchase intentions have a p-value of 0.004 ; where this value is less than the Alpha used is 5\% (0.05). This shows that there is a significant positive effect between product qualities on repurchase intention, with a coefficient value of 0.419 . The addition of customer satisfaction as a mediator gives a different effect on the direct relationship of product quality to repurchase intentions. Mediation testing of customer satisfaction is done by calculating the value of Variance Accounted For (VAF) which can be seen in Table 2. In Table 2 , it can be seen that before mediation, input into the product quality model has a direct effect on a significant positive repurchase intention with a coefficient of 0.343 . Then after mediating consumer satisfaction (M) is entered into the model, customer satisfaction has a direct influence on the intention to buy back a significant positive of 0.456 . Product quality has a direct effect on positive repurchase intention significantly of 0.419 . Product quality has a direct effect on significant positive customer satisfaction of 0.753 . The indirect effect between product quality and repurchase intention is 0.343 . The total influence possessed between consumer satisfaction with repurchase intentions of 0.456; the effect of total product quality with repurchase intentions of 0.768; and the total effect between product quality and customer satisfaction is 0.757 .

Table 3

Direct effects, indirect effects, and total variable effects and VAF

\begin{tabular}{lccc}
\hline Variable & Coefficient & $\begin{array}{c}\text { T Statistic } \\
(|\mathrm{O} / \mathrm{STDEV}|)\end{array}$ & $\begin{array}{c}\text { P-Value } \\
\text { Product Quality -> Repurchase Intention }\end{array}$ \\
& Direct Effect & 0,003 \\
Consumer Intention -> Repurchase Intention & 0,338 & 3,035 & 0,001 \\
Product Quality -> Consumer Satisfaction & 0,456 & 0,000 \\
Product Quality -> Repurchase Intention & 0,753 & 3,287 & 0,004 \\
& 0,419 & 11,567 & 0,003 \\
Product Quality -> Repurchase Intention & Indirect Effect & 2,864 & \\
& 0,343 & 3,035 & 0,001 \\
Consumer Satisfaction -> Repurchase Intention & Total Effect & 0,456 & 0,000 \\
Product Quality -> Consumer Satisfaction & 0,757 & 3,287 & 0,000 \\
Product Quality -> Repurchase Intention & 0,768 & 11,567 & 13,477 \\
\hline
\end{tabular}

$$
\begin{aligned}
V A F & =\frac{\text { Indirect Effect }}{\text { Total Effect }} \\
V A F & =\frac{0,343}{0,768} \\
& =0,447
\end{aligned}
$$

\section{Effect of product quality on repurchase intentions}

Based on the data presented in Table 3 it is known that product quality has a significant positive effect on repurchase intentions. So it can be concluded that the higher the quality of products owned by Berrybenka.com, the higher the intention to repurchase consumers of fashion products Berrybenka.com in Denpasar City. The value of loading factors on the product quality variable is vulnerable from 0.787 to 0.857 . It can be considered an indicator that is used enough to represent the product quality variable. The loading factor value on the repurchase intention variable is at a vulnerable 0.931 up to 0.950 , it can be considered an indicator that is used enough to represent the repurchase intention variable.

Sari, D. A. T., \& Giantari, I. G. A. K. (2020). Role of consumer satisfaction in mediating effect of product quality on repurchase intention. International Research Journal of Management, IT and Social Sciences, 7(1), $217-226$. 
The results of this study are known to be an average value that is above the average value of product quality variables are, performance (3.78), features (3.80), conformance to specification (3.78), aesthetic (3.80), perceived quality (3.76) and the repurchase intention variable is known to be an average value that is above the average value of the repurchase intention variable is anticipate repeat purchase (3.60).

This study obtained the results that the quality of Berrybenka.com products can have implications for the intention to repurchase the product, where consumers assume that the quality of Berrybenka.com brand products that they have felt can increase the intention to repurchase Berrybenka.com fashion products in the future. This finding is in line with the results of a study conducted by Mirabi et al. (2015). Mirabi et al. (2015), investigated the factors influencing the purchase intention of Bono brand tile customers, based on the results of this study, product quality variables, and advertising had the highest impact on customer purchase intentions. This is according to Mirabi et al. (2015), will result in continuous product quality improvement that can bring high results for the company. The findings made by Sullivan et al. (2018), shows the product evaluation factor, namely the quality perceived by consumers is important in determining repurchase intentions. Research conducted by Goh et al. (2016), shows that product attributes significantly influence consumer intentions for repeat purchases. Sulaiman et al. (2017), examined the online purchase intention and found that product factors were the factors that most influence online purchase intention. Jefry et al. (2014), tested the role of mineral water product package quality in packaging and the results showed that thicker water bottles were considered to be of higher quality compared to thinner bottled water bottles and this difference ultimately affected customers in encouraging repurchase intentions.

\section{Effect of product quality on customer satisfaction}

Based on the data presented in Table 5.11 it is known that product quality has a significant positive effect on customer satisfaction. So it can be concluded that the higher the quality of products owned by Berrybenka.com, the higher the customer satisfaction. The value of loading factors on the product quality variable is vulnerable from 0.787 to 0.857 . It can be considered an indicator that is used enough to represent the product quality variable. The loading factor value on the variable of customer satisfaction is vulnerable 0.859 to 0.868 can be considered an indicator that is used sufficiently represents the variable customer satisfaction. The results of this study are known to be an average value that is above the average value of product quality variables are, performance (3.78), features (3.80), conformance to specification (3.78), aesthetic (3.80), perceived quality (3.76) and the variable customer satisfaction is known the average value that is above the average value of the variable customer satisfaction is a satisfying experience (3.90).

Product quality is the thing that needs to get the most attention from the company/manufacturer considering the quality of a product is closely related to the problem of customer satisfaction which is one of the targets, especially in the marketing division Good product quality will later give satisfaction to consumers who have consumed the product. According to Kotler \& Keller (2009), consumer satisfaction depends on the quality of a product. Zhang et al. (2013) found that customer satisfaction is determined by the performance of product attributes where to satisfy customer management must first identify the performance of various attributes so that management is required to invest in product attributes to achieve the highest level of satisfaction. Research conducted by Pesoth (2015), also shows that product quality has an effect on cigarette customer satisfaction. Razak et al. (2016), found that product quality affects consumer satisfaction of toothpaste products.

\section{Effect of customer satisfaction on repurchase intentions}

Based on the data presented in Table 3 it is known that consumer satisfaction has a significant positive effect on repurchase intentions. So it can be concluded that the higher the satisfaction felt by Berrybenka.com consumers, the higher the intention to repurchase Berrybenka.com fashion products in Denpasar City. The value of loading factors on the variable of consumer satisfaction is vulnerable at 0.859 to 0.868 can be considered an indicator that is used sufficiently represents the variable customer satisfaction. The loading factor value on the repurchase intention variable is at a vulnerable 0.931 up to 0.950 , it can be considered an indicator that is used enough to represent the repurchase intention variable. The results of this study note the average value that is above the average value of the variable customer satisfaction is a satisfying experience (3.90) and the variable repurchase intention is known that the average value is above the average value of the variable repurchase intention is anticipate repeat purchase $(3,60)$.

Consumer satisfaction is an important thing to consider in business. Consumer satisfaction will encourage consumers to buy and re-consume the products they have consumed (Martini et al., 2018). The results of this study are in line with Lin (2014), finding that consumer satisfaction is a vital driver of repurchase intentions on online shopping, 
Chang et al. (2014), also found that customer satisfaction had a significant effect on repurchase intention and Yulianti (2014), found that satisfaction had a positive and significant effect on customer purchase intentions. Adekunle \& Jones (2018), conducted research conducted in Nigeria on smartphone products showing that the intention to repurchase a smartphone in that country is influenced by the satisfaction felt by consumers of these products. Domfeh et al. (2018), conducted a study of University of Cape Coast students and found that consumer satisfaction could influence purchase intentions in students in Ghana.

\section{The Role of customer satisfaction on mediating the effect of product quality on repurchase intentions}

Based on the data obtained in Table 3 shows that the addition of customer satisfaction as a mediating variable gives a different effect on the direct relationship of product quality to repurchase intention. Mediation testing of customer satisfaction is done by calculating the value of Variance Accounted For (VAF) which can be seen in Table 5.12. The role of consumer satisfaction as a mediator has a VAF value of 0.477 (44.7\%). These results indicate that consumer satisfaction has a role as a partial mediator between product quality and consumer intention to buy Berrybenka.com in Denpasar. Based on the calculation results in Table 5.12 shows that customer satisfaction has a role as a mediating relationship between product qualities and repurchase intention, so the hypothesis stating that customer satisfaction acts as a mediating relationship between product qualities and repurchase intention can be accepted. This shows that product quality and customer satisfaction are important factors in increasing the intention to re-buy Berrybenka.com fashion products in Denpasar City. Consumer satisfaction is one thing that must be considered by the company in order to achieve company goals. Consumer satisfaction achieved through the quality of a company's products can later increase the intention to repurchase the company's products.

The results of this study are in line with research conducted by Ishaq et al. (2014), which shows the role of customer satisfaction as a mediating variable of perceived quality, corporate image and customer value on customer loyalty. The role of mediation by consumer satisfaction is also seen in research conducted by Domfeh et al. (2018), the research shows that customer satisfaction can mediate celebrity advertising and celebrity personality towards purchase intention in the telecommunications industry in Ghana. Chang et al. (2014), found that consumer satisfaction had a significant effect on repurchase intention on food products sold online in Taiwan. Goh et al. (2016), also shows the mediating role of customer satisfaction in the influence of product attributes on the intention to repeat purchases of smartphone products in Malaysia. Research conducted by Moeslehi \& Farideddin (2016), consumer satisfaction is influenced by the price promotion of coffee shop products in Isfahan and then consumer satisfaction affects the intention of repeated product purchases.

\section{Conclusion}

The results of research that have been done show that to increase the intention to repurchase it is necessary to pay attention to the factors of product quality and customer satisfaction. This shows that product quality and customer satisfaction greatly affect consumer behavior in achieving consumer repurchase intentions to later be able to achieve company goals. Companies should be able to provide good quality products for consumers. The results showed the average value of respondents to the indicators of reliability, durability, and the below of average value of other product quality variable indicators, so the company is expected to have more attention related to the response of these variable indicators for example by taking into account the possibility of the product experiencing damage when accepted by consumers, good product durability, and also product comfort when used for Berrybenka.com consumers. The company is also expected to be able to make consumers feel shopping at Berrybenka.com is a wise decision, right and satisfied with the services provided. This is because the response to the value of the indicator is below the average value so that the company is expected to be able to improve these indicators.

On the variable repurchase intention, the company is expected to be able to maintain the level of consumer expectations to buy back Berrybenka.com products later and also encourage consumers to be able to continue buying fashion products on Berrybenka.com in the future. This is because the response to the value of the indicator is below the average value so that the company is expected to be able to improve these indicators. Attention to the quality of the product will be able to increase customer satisfaction, it is due to the feeling of satisfaction by consumers after feeling the quality of the products they have purchased. The satisfaction that consumers have felt will have an impact on their repurchase intention behavior in the future. The higher the satisfaction felt by consumers, the higher the intention to repurchase in the future.

Sari, D. A. T., \& Giantari, I. G. A. K. (2020). Role of consumer satisfaction in mediating effect of product quality on repurchase intention. International Research Journal of Management, IT and Social Sciences, 7(1), 217-226. 
Conflict of interest statement

The authors declared that they have no competing interests.

Statement of authorship

The authors have a responsibility for the conception and design of the study. The authors have approved the final article.

Acknowledgments

We are grateful to two anonymous reviewers for their valuable comments on the earlier version of this paper. 
References

Adekunle, S. A., \& Ejechi, J. O. (2018). Modelling repurchase intention among smartphones users in Nigeria. Journal of Modelling in Management. https://doi.org/10.1108/JM2-12-2017-0138

Assauri, S. (2015). Manajemen Pemasaran (empat belas). Jakarta: Rajawali Pers.

Chang, S. C., Chou, P. Y., \& Lo, W. C. (2014). Evaluation of satisfaction and repurchase intention in online food group-buying, using Taiwan as an example. British Food Journal. https://doi.org/10.1108/BFJ-03-2012-0058

Domfeh, H. A., Kusi, L. Y., Nyarku, K. M., \& Ofori, H. (2018). The Mediating Effect of Customer Satisfaction in the Predictive Relation between Celebrity Advertising and Purchase Intentions in Telecom Industry in Ghana: University Students' Perspective. International Journal of Business and Management Invention (IJBMI), 7(3), 4054.

Ferdinand, A. (2014). Pedoman Penelitian Untuk Penulisan Skripsi Tesis dan Disertasi Ilmu Manajemen: Metode Penelitian Manajemen: Semarang: Badan Penerbit Universitas Diponegoro.

Goh, S. K., Jiang, N., Hak, M. F. A., \& Tee, P. L. (2016). Determinants of smartphone repeat purchase intention among malaysians: a moderation role of social influence and a mediating effect of consumer satisfaction. International Review of Management and Marketing, 6(4), 993-1004.

Irnandha, A. (2016). Pengaruh Kualitas Layanan Terhadap Loyalitas Pelanggan Yang Dimediasi Oleh Kepuasan Pelanggan Jasa Pengiriman Jalur Darat (Studi Kasus Kepuasan Pelanggan Jne Cabang Hijrah Sagan Yogyakarta). Jurnal Manajemen Bisnis Indonesia (JMBI), 5(6), 660-669.

Ishaq, M. I., Bhutta, M. H., Hamayun, A. A., Danish, R. Q., \& Hussain, N. M. (2014). Role of corporate image, product quality and customer value in customer loyalty: Intervening effect of customer satisfaction. Journal of Basic and Applied Scientific Research, 4(4), 89-97.

Jeffrey, S., Singh, J., Metcalf, L. E., \& Danes PhD, J. (2014). The impact of consumer product package quality on consumption satisfaction, brand perceptions, consumer investment and behavior. Journal of Applied Packaging Research, 6(1), 4.

Kotler, P., \& Keller, K. L. (2009). Marketing management. 1. vyd. Praha: Grada, 2007, 788 s.

Lin, C., \& Lekhawipat, W. (2014). Factors affecting online repurchase intention. Industrial Management \& Data Systems, 114(4), 597-611. https://doi.org/10.1108/IMDS-10-2013-0432

Lin, C., \& Lekhawipat, W. (2014). Factors affecting online repurchase intention. Industrial Management \& Data Systems, 114(4), 597-611. https://doi.org/10.1108/IMDS-10-2013-0432

Magatef, S. G. (2015). The impact of tourism marketing mix elements on the satisfaction of inbound tourists to Jordan. International Journal of Business and Social Science, 6(7), 41-58.

Mirabi, V., Akbariyeh, H., \& Tahmasebifard, H. (2015). A study of factors affecting on customers purchase intention. Journal of Multidisciplinary Engineering Science and Technology (JMEST), 2(1).

Moslehi, H., \& Haeri, A. F. (2016). Effects of Promotion on Perceived Quality and Repurchase Intention. International Journal of Scientific Management and Development, 4(12), 457-461.

Oghojafor, B. E. A., Ladipo, K. A. P., Ighomereho, O. S., \& Odunewu, A. V. (2014). Determinants of customer satisfaction and loyalty in the Nigerian telecommunications industry.

Pesoth, M. C. (2015). Pengaruh Kualitas Produk, Packaging, Dan Brand Image Terhadap Kepuasaan Pelanggan Pada Perusahaan Rokok Dunhill Di Kota Manado. Jurnal EMBA: Jurnal Riset Ekonomi, Manajemen, Bisnis dan Akuntansi, 3(3). https://doi.org/10.35794/emba.v3i3.10115

Razak, I., Nirwanto, N., \& Triatmanto, B. (2016). The impact of product quality and price on customer satisfaction with the mediator of customer value. Journal of Marketing and Consumer Research, 30(1), 59-68.

Sugiyono. (2017). Metode Penelitian Kuantitatif, Kualitatif dan R\&D. Bandung:Alfabeta.

Sulaiman, Y., Yusr, M. M., \& Ismail, K. A. (2017). The influence of marketing mix and perceived risk factors on online purchase intentions. International Journal of Research in Business Studies and Management, 4(9), 30-40.

Sullivan, Y. W., \& Kim, D. J. (2018). Assessing the effects of consumers' product evaluations and trust on repurchase intention in e-commerce environments. International Journal of Information Management, 39, 199-219. https://doi.org/10.1016/j.ijinfomgt.2017.12.008

Yulianti, N. M. D. R., Suprapti, N. W. S., \& Yasa, N. N. K. (2014). Pengaruh Citra Toko terhadap Kepuasan Pelanggan dan Niat Beli Ulang pada Circle K di Kota Denpasar. Matrik: Jurnal Manajemen, Strategi Bisnis dan Kewirausahaan.

Zhang, Z., Jiang M., \& Xiangyang Li. (2013). Refining the relationship between attribute performance and customer satisfaction in the Chinese hospitality industry. Total Quality Management. Vol. 24, No. 12. Pp:1364-1375.

Sari, D. A. T., \& Giantari, I. G. A. K. (2020). Role of consumer satisfaction in mediating effect of product quality on repurchase intention. International Research Journal of Management, IT and Social Sciences, 7(1), 217-226.

https://doi.org/10.21744/irjmis.v7n1.839 
Martini, L. K. B., Suardana, I. B. R., \& Astawa, I. N. D. (2018). Dimension Effect of Tangibles, Reliability, Responsiveness, Assurance, Empathy, Leadership towards Employee Satisfaction. International Research Journal of Management, IT and Social Sciences, 5(2), 210-215. Retrieved from https://sloap.org/journals/index.php/irjmis/article/view/76

Saputra, L. A. A., Surati, -, \& Saufi, A. (2019). Mediation role of job satisfaction towards effect of conflict roles on organizational commitment. International Journal of Social Sciences and Humanities, 3(2), 165-175. https://doi.org/10.29332/ijssh.v3n2.308 